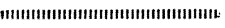 \\ 論文

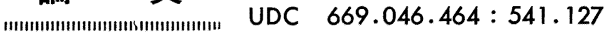 \\ 未反応核モデルにおける混合律速反応速度式の \\ 速度パラメータの修正決定法
}

\author{
村 山武 昭*.小 野 陽 一*
}

\section{Modified Method for the Determination of the Parameters Included in the Mixed-control Rate Equation of Unreacted-core Model}

\section{Takeaki MUrAyama and Yöichi ONO}

\section{Synopsis :}

To determine rate parameters for the gaseous reduction of an iron oxide pellet, mixed-control plot proposed by T. YAGI and Y. Ono (Trans. ISIJ, 8 (1968), 377.) has been widely used. The method, however, can not be properly applied to the case where the reduction is retarded at the beginning. In this paper, a modified method to avoid any influence of the initial delay of reduction on the mixed-control plot is proposed. In this method a straight line representing the mixed-control plot is drawn to pass through an observed data point $\left(t=t_{1}, F=F_{1}\right)$ other than the initial point. The point $\left(t=t_{1}, F=F_{1}\right)$ is selected so that the value of $F_{1}$ may be relatively low and the mean relative residual of the calculated reaction time from the observed time, $\Delta t_{r}$, can be minimum.

\section{1. 緒言}

酸化鉄ペレットをガスで還元する場合，Fig. 1 に示 すように昇温中に流した不活性ガス $\left(\mathrm{N}_{2}\right)$ から還元ガス $\left(\mathrm{CO}-\mathrm{CO}_{2}\right)$ に切り換えてもすぐには反応は開始せず，あ る程度時間を経た後に反応が始まる．また，反応が開始 しても，なかには得られる還元率曲線がシグモイド型に なる場合もある，この原因として，還元生成物の核生成 に伴う潜伏期の影響1) とか，昇温中に流していた不活性 ガスと還元ガスとの混合希釈によるペレット近傍でのバ ルクガス濃度の変化の影響2)など，いくつかの説が出さ れているが，まだ明確ではない，還元による重量減を記 録紙に記録させる場合は重量変化の開始点を原点にする ことが多いが，カセトメーターでバネの変位を観察して 測定する場合には原点の決定が困難である.

従来，酸化鉄ペレットのガス還元速度の解析には未反 応核モデルが一般に使用されている3). その速度パラメ 一タの決定には YAGI and ONo の混合律速の解法3) が 一般に使用されている。 しかし，近江ら²)の場合を除け ば上記の反応開始時の反応遅延現象の影響は考慮されて

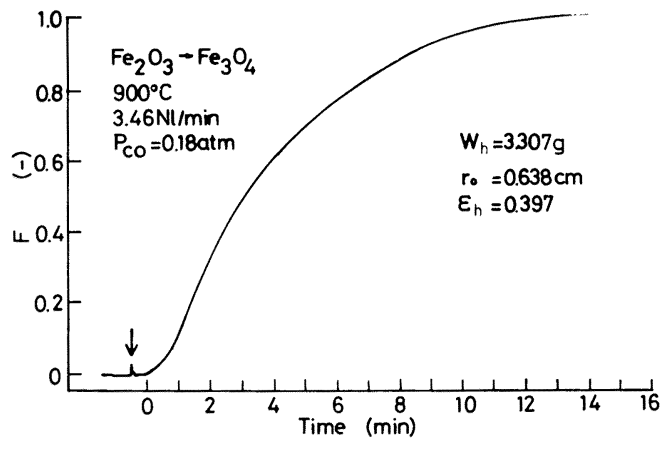

Fig. 1. Example of initial delay of reduction. Arrow stands for the beginning of replacement of $\mathrm{N}_{2}$ gas with $\mathrm{CO}-\mathrm{CO}_{2}$ gas mixture in the reaction tube. Time zero represents the actual starting point of reduction.

いない，従つて，上記の方法で得られる速度パラメータ には反応開始時の反応遅延現象の影響が含まれている. 近江 ${ }^{2)}$ は反応初期のガス切り換えによる濃度変化の影 響を考慮した解法を示しているが，前述のように反応初 期では必ずしもガス切り換えによる濃度変化だけが影響

昭和 55 年 6 月本会九州支部講演大会，10 月本会講演大会にて発表 昭和 55 年 8 月 29 日受付 (Received Oct. 29, 1980)

* 九州大学工学部 工博 (Faculty of Engineering, Kyushu University, 6-10-1 Hakozaki Higashi-ku Fukuoka 812) 
を及ぼすのではないと考觉られるし，また彼らの方法で はガス切り換え時の還元ガスの 濃度を近似式で表すた め，さらにその式のパラメータの值を決定する必要があ り, 複雑である. そこで本研究では, 反応初期の部分を 除外し，還元データ上で反応初期の特異現象の影響を受 けていないと考えられる点（反応時間 $t=t_{1}$, 還元率 $F=$ $F_{1}$ ）を基準点とし，その点を理論曲線が必ず通るとした 場合の混合律速の解法を示すとともに基準点の選び方に ついて検討を加えたので報告する.

な特，本報の解法は，還元データの中で未反応核モデ ルがあてはまる部分（見掛上あてはまる部分も含む）に のみ適用することを前提としている. 未反応核モデルが 西てはまらない場合には，もちろん他のモデルで検討す べきである。

\section{2. 解 析 方 法}

一般に，ガス境膜内物質移動過程, 生成物層内ガス拡 散過程, 界面化学反応過程を考慮した未反応核モデルの 総括反応速度 $\dot{n}$ は次式で与えられる3).

$$
\begin{aligned}
\dot{n} & =-4 \pi r_{i}^{2} d_{o} \frac{d r_{i}}{d t} \\
& =\frac{4 \pi r_{o}^{2}\left(C_{A b}-C_{A e}\right)}{\frac{1}{k_{f}}+\begin{array}{c}
r_{o}\left(r_{o}-r_{i}\right) \\
r_{i} D_{s}
\end{array}+\left(\frac{r_{o}}{r_{i}}\right)^{2}} \frac{1}{(1+1 / K e) k_{c}}
\end{aligned}
$$

ここで, 未反忘核半径を $r_{i}$, 還元率を $F$, 生成物層の相 対厚さを $f$ とすると，それらの間には次の関係がある。

$$
f=1-\left(r_{i} / r_{o}\right)=1-(1-F)^{1 / 3}
$$

この関係を(1) 式に代入し, (1) 式を(3)の条件下で解

くと, (4)式が得られる.

$$
\left.\begin{array}{l}
t=t_{1} \text { で } F=F_{1}\left(f=f_{1}, r_{i}=r_{1}\right) \\
t=t \text { で } F=F\left(f=f, r_{i}=r_{i}\right)
\end{array}\right\}
$$

$$
\begin{aligned}
& \frac{\left(C_{A b}-C_{A e}\right)\left(t-t_{1}\right)}{r_{0} d_{o}\left(f-f_{1}\right)}-\frac{1}{3 k_{f}} \\
& \times\left\{3-3\left(f_{1}+f\right)+f^{2}+f f_{1}+f_{1}^{2}\right\} \\
& =\frac{r_{o}}{6 D_{s}}\left\{3\left(f_{1}+f\right)-2\left(f^{2}+f f_{1}+f_{1}^{2}\right)\right\} \\
& +\frac{1}{(1+1 / K e) k_{c}}
\end{aligned}
$$

ここで

$$
\begin{aligned}
Y & =\frac{\left(C_{A b}-C_{A e}\right)\left(t-t_{1}\right)}{r_{o} d_{o}\left(f-f_{1}\right)} \\
& -\frac{1}{3 k_{f}}\left\{3-3\left(f_{1}+f\right)+f^{2}+f f_{1}+f_{1}^{2}\right\} \cdots( \\
X & =3\left(f+f_{1}\right)-2\left(f^{2}+f f_{1}+f_{1}^{2}\right) \cdots \cdots \cdots \cdots \cdots
\end{aligned}
$$

と置くと，(4)式は次のようになる.

$$
Y=\frac{r_{o}}{6 D_{s}} X+\frac{1}{(1+1 / K e) k_{c}}
$$

したがつて，ガス境膜内物質移動係数 $k_{f}$ の値を推算式 で別に求め，還元データをもとに基準点 $\left(t_{1}, F_{1}\right)$ を決 め, $Y$ 対 $X$ のプロットをすると, 未反応核モデルがあて はまれば $Y$ との関係は值線になり, その直線の傾きか ら粒内有効拡散係数 $D_{s}$, 切片から化学反応速度定数 $k_{c}$ の值を求めることができる.この $Y$ 対 $X$ のプロットのこ とを今後, 混合律速プロットと呼ぶことにする. この力 法を使用すると反応初期の特異現象の影響を除外して解 析することができる。なお $t_{1}=0, F_{1}=0$ とした場合が 従来の混合律速の解法に相当する. Fig. 2 には上記の 解法を図式的に示すとともに，眓の上方に基準還元率 $F_{1}$ が $0,0.3,0.5,0.7$ の場合に $X$ 軸上で各還元率 $F$ の目盛がどこにくるかを示した. 図のように基準還元率 $F_{1}$ が高くなるにつれ,プロットの範囲は右側へ移行し, しかもその幅はせまくなる. しかし，基準点がかわつて も, それらの基準点がすへて同じ理論還元率曲線上にあ るかぎり，すなわち， $D_{s}, k_{c}$ が一定であるかぎり，Y対

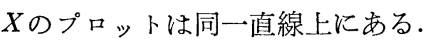

次に上述のようにして求めた $D_{s}, k_{c}$ の值を使用し, (4) 式を用いて還元率の各測定点に対する反応時間 $t=$ $t_{c i}$ を計算する. 反応時間の測定值を $t_{d i}$, データ数を $N$ とし，次式により，測定値と計算值の一致の程度を示す 平均相対残差 $\Delta t_{r}$ を求める.

$$
\Delta t_{r}=\frac{1}{N} \sum_{i=1}^{N}\left|\frac{t_{d i}-t_{c i}}{t_{d i}}\right|
$$

この $\Delta t_{r}$ が 小さいほど測定值と計算值が一致してい ると言える。

な特, 試行計算には, 以前, 著者らの研究室で得られ

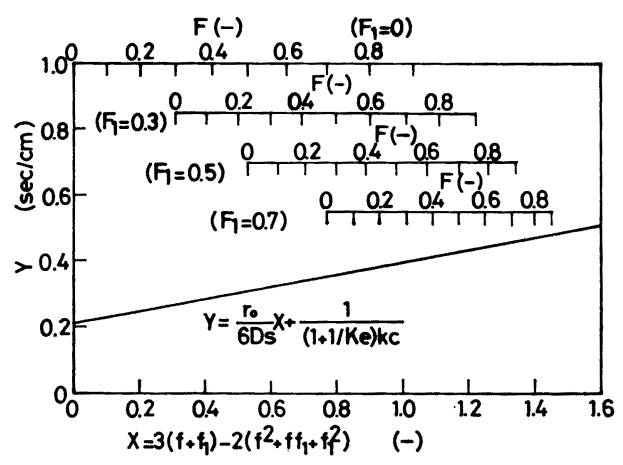

Fig. 2. Mixed control plot of $Y$ vs. $X$ for the determination of $k_{c}$ and $D_{s}$. (The upper four scales of fractional reduction $F$ represent the range of the plot for four different values of $F_{1}$.) 
た $\mathrm{CO}-\mathrm{CO}_{2}$ 混合ガスによる酸化鉄ペレットの段階ごと 還元のデータ7）を使用した。また，ガス境膜内物質移動 係数 $k_{f}$ の值は RANZ ら4) の式から求められる值に収 支抵抗卓を加味したもの的を使用した。

上記データに本報の解法を適用し，基準点 $\left(t_{1}, F_{1}\right)$ の 值を種々変えて， $D_{s}, k_{c}, \Delta t_{r}$ の值を求め，基準点のと り方について検討を加えた.

\section{3. 結果}

本報の解法を適用し試行計算を行つた中から典型的な 3 つの場合についてその結果を以下に述べる.

Fig. 3〜5 飞代表的な 3 つの場合の還元率曲線を示 す. 図中, 計算曲線を求めるのに使用した速度パラメー タの值は本報の解法で求めた值である。なお，Fig. 3〜 5 はほとんぞ類似した条件で還元を行つたにもかかわら ず，図に示すような 3 つのケースを生じたのは次の理由

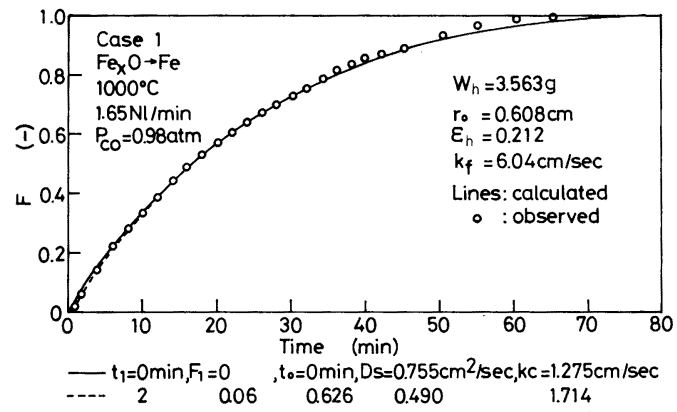

Fig. 3. Comparison of the observed reduction curve of wustite to iron with the two curves calculated from Eq. (4) by using the values of $(0 \mathrm{~min}, 0)$ and $(2 \mathrm{~min}, 0.06)$ for $\left(t_{1}, F_{1}\right)$.

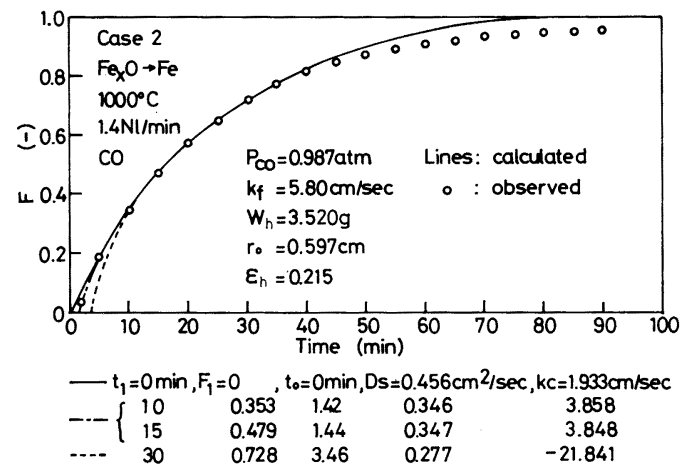

Fig. 4. Comparison of the observed reduction curve of wustite to iron with the four curves calculated from Eq. (4) by using the values of $(0 \mathrm{~min}, 0)$, $(10 \mathrm{~min}, 0.353), \quad(15 \mathrm{~min}, 0.479)$, and $(30 \mathrm{~min}$, 0.728 ) for $\left(t_{1}, F_{1}\right)$ respectively.

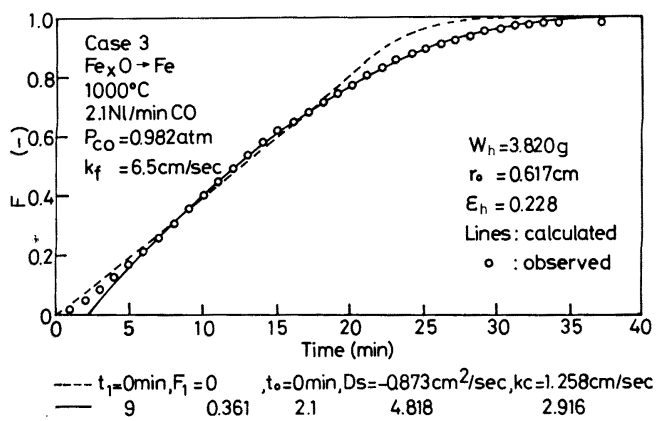

Fig. 5. Comparison of the observed reduction curve of wustite to iron with the two curves calculated from Eq. (4) by using the values of $(0 \mathrm{~min}, 0)$ and $(9 \mathrm{~min}, 0.361)$ for $\left(t_{1}, F_{1}\right)$ respectively.

による１つの原因は，試料ペレットの作製者，作製の 時期, 試料粉末のロットなどが異なつている点である. たとえば，Case 2 では Case 1,3 と異なり,反応末期に 還元停滞が認められるが，これは上述の点が主な原因で あると思われる。また， Case 2 で Case 1 に比べて反 応の開始が遅れているのは，ガス切り換え時にコック操 作に手間どつたためであると思われる．Case 3 ではガ スの流路に容量の大きな積算型流量計（1 周期通過量 1 l) ならびに乾燥塔 $(500 \mathrm{cc})$ を加えたため，ガス切り 換えに時間を要し，還元率曲線がシグモイド型となつ た.

Fig. 3 は反応開始時に反応の遅れがほとんどない場 合 (Case 1) である. 図には還元開始点を原点にした場 合（図中実線）と $t_{1}=2 \mathrm{~min}, F_{1}=0.06$ を基準点にした 場合 (図中点線) の計算値を示した. 図のように還元率 曲線上では両者に差はあまりないが，速度パラメータの 值が少し異なる。

Fig. 4 は反応開始時に反応の 遅れが少しある場合 (Case 2) である. 図に示すように基準点を還元データ 上で $t_{1}=10 \mathrm{~min}, F_{1}=0.353$ かあるいは $t_{1}=15 \mathrm{~min}$ ， $F_{1}=0.479$ にした場合に計算値が 測定值とよく一致す る. $t_{1}=0 \mathrm{~min}, F_{1}=0$ を基準点にしても還元率曲線上で は計算值と測定值に差はあまりないが， $k_{c}$ の值が $t_{1}=$ $10 \mathrm{~min}, F_{1}=0.353$ の場合に比べて半分くらい小さくな る.また， $F_{1}=0.728$ と高還元率側で基準点をとると， 還元率曲線上で反応初期に計算値が測定值からかなりず れてくるし，また $k_{c}$ の值も負の值になつている.

Fig. 5 は還元率曲線がシグモイド型になる場合 (Case 3）である. 基準点を還元データ上で $t_{1}=0 \mathrm{~min}, F_{1}=0$ とすると，粒内有効拡散係数 $D_{s}$ の值が負になる。 た，還元率曲線上で計算值が測定值からかなりずれる. 
一方，基準点を還元データ上で $t_{1}=9 \mathrm{~min}, F_{1}=0.361$ とすると，還元率曲線は反応初期を除㚈，測定値と計 算值がよく一致する. しかし， $D_{s}$ の值は他の 2 つの Case と比較して過大な值となつている.この点につい ては今後他のモデルでの検討を必要とする．ここでは， 本報の解法を使用すれば，この場合でも見掛上，計算值 を測定值と一致させることができると言うにとどめる.

このように本報の解法を使用すれば，反応初期に特異 な現象がある場合でも還元率曲線の計算値を測定值と一 致させることができる.

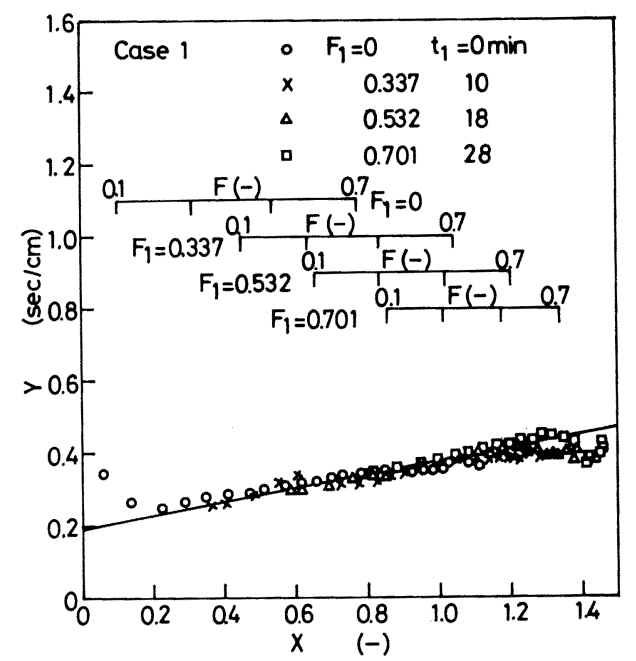

Fig. 6. Mixed control plot for the determination of $k_{c}$ and $D_{s}$. (Case 1)

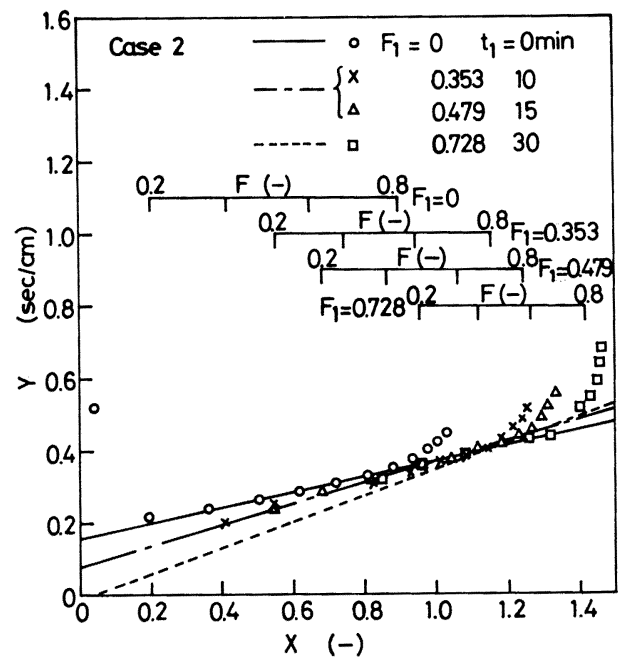

Fig. 7. Mixed control plot for the determination of $k_{c}$ and $D_{s}$. (Case 2)

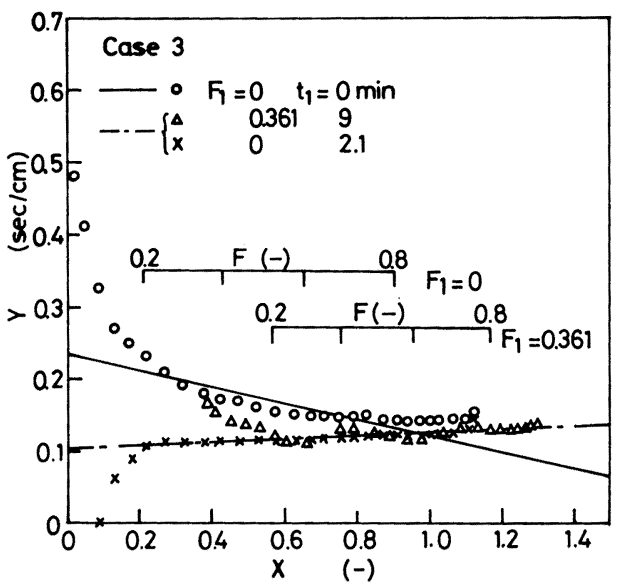

Fig. 8. Mixed control plot for the determination of $k_{c}$ and $D_{s}$. (Case 3)

次に上記の 3 つの場合の混合律速プロット（ $Y$ 対 $X$ の プロット)を示す．Fig. 6 は反応開始時に反応の遅れ がほとんどない場合である，図に示すように，どの点を 基準点にしてもほとんど同じ直線上にプロットが乗るこ とがわかる. この場合, 直線は還元率 $F=0.1 \sim 0.7$ の

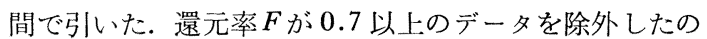
は，還元データ上で図に示すよらに読み取り誤差が大き く，還元率曲線に少しら衫りが認められたからである. 図には基準還元率 $F_{1}=0,0.337,0.532 ， 0.701$ の場合 に直線を引く対象とした還元率の区間も図示した．基準 点が還元データ上で $t_{1}=0 \mathrm{~min}, F_{1}=0$ の場合（図中 印), 低還元率側で直線から上方へ大きくへだたつた点 （たとえば○印の一番左の点）があるが，これらの点も 基準点をかかえると直線上借る（×印の一番左の点）.

Fig. 7 は反応開始時にわずかに反応の遅れがある場 合である. $F_{1}=0$ の場合打よび還元未期を除けば，基準 点をかえてもほ涪同じ直線上にプロットは乗つている. ただし， $F_{1}=0.728$ の場合はプロットの幅もせまく，乙 かも $Y$ 軸から遠くなり，線も引きにくいため，直線の切 片が負になるといら事態も生じている。なお，この場 合，Fig. 4 に示すように反応末期に反応停滞がわずか に認められるので，還元率 0.8 以上のデータを除外し， 直線は還元率 $F=0.2 \sim 0.8$ の間で引いた.また，図には それぞれの基準還元率の場合に直線を引く対象とした $X$ 軸上の区間も図示した．このように基準点を高還元率側 にすると，図のようにプロットの幅がせまくなり，乙か もY軸から遠くなるため， $Y$ 対 $X$ のプロットをしても直 線が引きにくい上に切片のばらつきが大となる，直線の 引きやすさなどから考光れば，基準点は低還元率側の方 
がよい.

Fig. 8 は還元率曲線がシグモイド型になる場合であ る. $F_{1}=0$ とした場合は直線の傾きが負になるが， $F_{1}=$ 0.361 にとれば傾きは正となる。しかし，まだプロット のばらつきはある程度大きい。このプロットから求まる 速度パラメータを使つて還元率曲線を求めると, $F=0$ の 時 $t_{1}=2.1 \mathrm{~min}$ となる. それで次に $t_{1}=2.1 \mathrm{~min}, F_{1}=$ 0 を基準点にしてプロットしたのがメ印のプロットであ る.このようにすると, 直線性も向上するし，プロット の幅も広くなるので，直線が引きやすい。な拈，直線は $F=0.2 \sim 0.8$ の間で引いた.

以上のように本報の解法を使用すれば，還元率曲線が シグモイド型になる場合でも正の值でしかも還元率曲線 をよく再現する速度パラメータを求めることができる. しかし，基準点はなるべく低還元率側が好ましい，高還 元率側を基準点にする必要がある場合は，一度，高還元 率側の点を基準点として $Y$ 対 $X$ のプロットを行い，速度 パラメータを求め，その速度パラメータを用いて還元率 曲線を再計算し， $F=0$ となる時間 $t_{0}$ を求め，さらに $t_{1}=t_{0}, F_{1}=0$ を基準点として 再度本報の方法で $Y$ 対 $X$ のプロットを行えばよい, 高還元率側を基準点にして $Y$ 対 $X$ のプロットを行い，そうして引いた直線が正しけれ ばその直線上に $t_{1}=t_{0}, F_{1}=0$ を基準点とした時のプロ ットが乗るはずである。

Fig. 9 には，Fig. 3〜5 の場合について還元率曲線

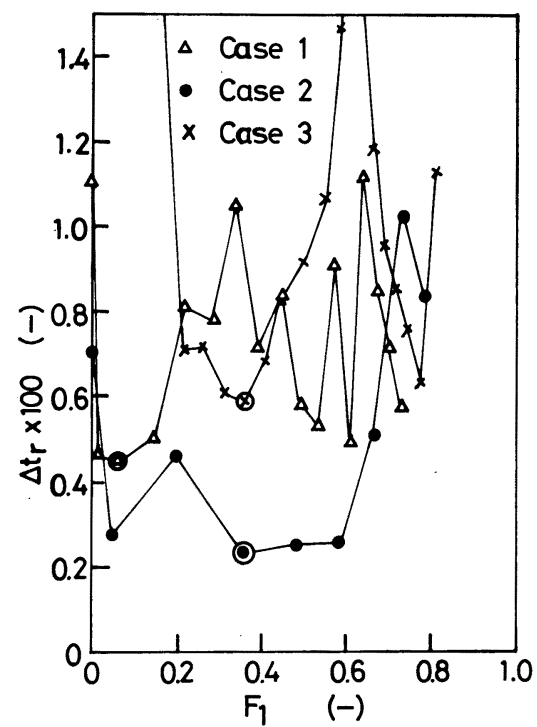

Fig. 9. Relation between mean relative residual, $\Delta t_{r}$ and reference fractional reduction, $F_{1}$.
の測定值と計算值の一致の程度を示す平均相対残差 $\Delta t_{r}$ が基準還元率 $F_{1}$ によつてどのように変化するかを示し た.なお，この $\Delta t_{r}$ を求めるための還元データの範囲 は，Fig. 6〜8 で直線を引く対象とした還元率の範囲

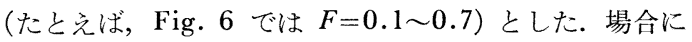
よつて異なるが， $F_{1}$ が比較的低い方が $\Delta t_{r}$ は小さい. $F_{1}$ が高くなると， $Y$ 対 $X$ のプロットの幅がせまくなる ため直線が引きにくく，誤差が大きくなる. $\Delta t_{r}$ が最小 となる場合に誤差（相対残差）が一番小さくなる.ただ し， $\Delta t_{r}$ を判定基準にすると高還元率側で還元時間の測 定值と計算值の差 $\left|t_{d i}-t_{c i}\right|$ が大きくなる 可能性があ る. そこで， $\Delta t_{r}$ のかわりに平均残差

$$
\Delta t=\frac{1}{N} \sum_{i=1}^{N}\left|t_{d i}-t_{c i}\right|
$$

を判定基準にした場合についても検討したが， $\Delta t_{r}$ の場 合と大差なかつた。 ただ，各測定点で計算值が測定值か ら何パーセントずれているかといらことがわかる点，ま た， $\Delta t_{r}$ を判定基準とした場合，反応の前半でずれが大 きいことがあるという点で $\Delta t_{r}$ の方が $\Delta t$ よりも判定 基準として適当と言える。したがつて，基準点としては $\Delta t_{r}$ が最小となる点がよいと考えられる. しかし，もち ろん， $\Delta t_{r}$ が最小となつても $D_{s}$ や $k_{c}$ が負になる場合 は除外すべきである。 また，Case 2 の場合のように， 高還元率側で還元停滞を起す場合には，還元データの高 還元率側は未反応核モデルより，たと竞ば，生成鉄中の 酸素の桩散が律速としたモデル8)9)で解析した方がよく，

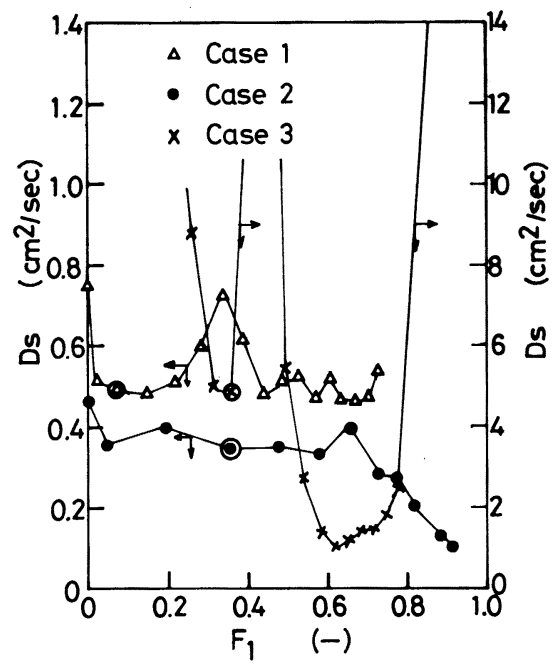

Fig. 10. Relation between diffusion coeficient in the product layer, $D_{s}$ and reference fractional reduction, $F_{1}$. The symbol $\bigcirc$ designates the point which corresponds to the minimum of $\Delta t_{r}$. 


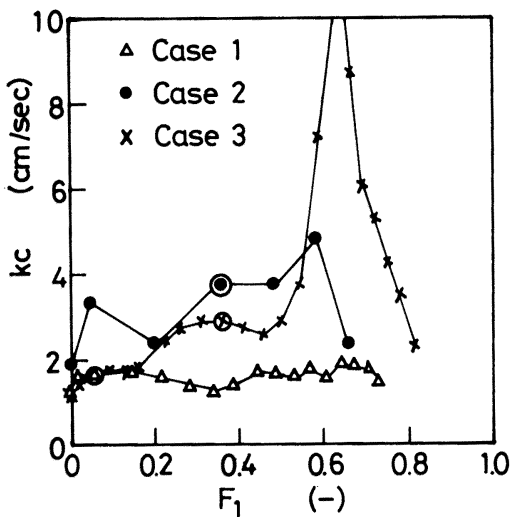

Fig. 11. Relation between chemical reaction rate constant, $k_{c}$ and reference fractional reduction, $F_{\mathbf{1}}$. The symbol $\bigcirc$ designates the point which corresponds to the minimum of $\Delta t_{r}$.

したがつて，本報の解析の対象からその部分（還元デー タの高還元率側部分）を除外した.

Fig. 10 には $Y$ 対 $X$ のプロット (Fig. 6〜8) の傾き から得られた粒内有効拡散係数 $D_{s}$ の值と基準還元率 $F_{1}$ の関係を示した. 未反応核モデルがあてはまれば，理 論的には $F_{1}$ によらず $D_{s}$ は一定となるはずであるが， 速度パラメータは還元率曲線のわずかな変動に対しても 敏感で大きく変動する. それで, Case 3 のように大き く変動する場合もあり，反応初期以外の点を $F_{1}$ として 任意に選んだとしても，必ずしも適当な值が得られると は限らない. Case 1,2 では， $F_{1}$ が比較的低い所ではほ ぼ一定になつており，この平均的な值を採用するという 方法も考えられる. しかし，平均值を採用するにして も，その際にばらつきの範囲をどこまで認めるかなどの 問題もあり，また，Case 3 のよらに平均值が求めにく い場合もあるので，この方法は必ずしも適当とは言えな い.ところが， $\Delta t_{r}$ が最小となる場合が前述のように一 番よく還元データを再現できるわけで， $\Delta t_{r}$ 最小の場合 の $D_{s}$ をパラメータとして採用するのが， Case 3 の場 合も含めて，最も妥当である.な拉，Fig. 10 中，○で 曲んだ点が $\Delta t_{r}$ が最小となる場合である。また， $F_{1}=0$ の場合は, いずれも $\Delta t_{r}$ 最小の場合の值より高めの $D_{s}$ の值を与える。

Fig. 11 には, 先ほどの $Y$ 対 $X$ のプロット (Fig. 6〜 8)の切片から求まる化学反応速度定数 $k_{c}$ の值と基準還 元率 $F_{1}$ の関係を示した. $F_{1}$ が比較的低いところでは $k_{c}$ は比較的一定になつている.図中○で囲んだ点が $\Delta t_{r}$ が最小となる場合である， $F_{1}=0$ の場合， $k_{c}$ はやや低め の值となる。

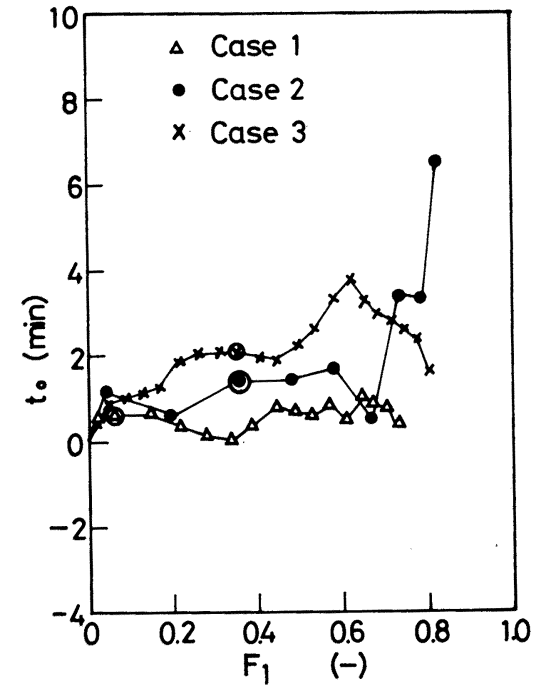

Fig. 12. Relation between starting reaction time calculated by Eq. (4), $t_{0}$ and reference fractional reduction, $F_{1}$. The symbol $\bigcirc$ designates the point which corresponds to the minimum of $\Delta t_{r}$.

前にも述べたように，本報の解法で求めた速度パラメ 一タを使用して還元率曲線を再計算すると， $F=0$ とな る時間 $t_{0}$ を求めることができる. Fig. 12 には $t_{0}$ と $F_{1}$ の関係を示した． $F_{1}$ が低いところでは $t_{0}$ はあまり 変化しない，この図から，ここで使用したデータの場 合, 測定值の $F=0$ となる時間 $t=0$ からのずれはあま り大きくないことがわかる，逆に言えば，このわずかの 違いが解析結果に大きな影響を及ぼしていると言える。

\section{4. 結言}

反応開始時の反応遅延現象の影響を除外した未反応核 モデルの混合律速の解法を示した. すなわち，還元デー タ上で反応初期の特異現象の影響を受けていないと考え られる点 $\left(t_{1}, F_{1}\right)$ を基準点とし，その点を理論曲線が必 ず通るとした場合の混合律速の解法を示した．その場 合，基準点としては，還元データの中でなるべく還元率 の低い範囲で平均相対残差 $\Delta t_{r}$ が最小となる $\left(t_{1}, F_{1}\right)$ を選ぶのがよいことがわかつた.

\section{記 号}

$C_{A b}:$ バルクガス濃度 $\left[\mathrm{mol} / \mathrm{cm}^{3}\right]$

$C_{A e}:$ 平衡濃度 $\left[\mathrm{mol} / \mathrm{cm}^{3}\right]$

$D_{s}:$ 粒内有効拡散係数 $\left[\mathrm{cm}^{2} / \mathrm{s}\right]$

$d_{o}:$ 被還元酸素濃度 $\left[\mathrm{g}-\mathrm{atom} / \mathrm{cm}^{3}\right]$

$F, F_{1}$ : 還元率，基準還元率 $[-]$

$f$ : 生成物層の相対厚さ [-]

$f_{1}: F=F_{1}$ の時の $f$ の值 $[-]$ 
$\mathrm{Ke}$ : 平衡定数 [-]

$k_{c}:$ 化学反応速度定数 $[\mathrm{cm} / \mathrm{s}]$

$k_{f}$ : ガス境膜内物質移動係数 $[\mathrm{cm} / \mathrm{s}]$

$P_{C O}: \mathrm{CO}$ 分圧 $[\mathrm{atm}]$

$r_{i}:$ 末反応核半径 $[\mathrm{cm}]$

$r_{0}:$ ペレット半径 $[\mathrm{cm}]$

$r_{1}: F=F_{1}$ の時の $r_{i}$ の值 $[\mathrm{cm}]$

$t, t_{0}, t_{1}$ : 反応時間, 反応開始時間, 基準反応時間 [ sec] or [ $\mathrm{min}]$

$W_{h}$ : へマタイトの状態でのペレット重量 [g $]$

$\varepsilon_{h}$ : へマタイトの状態におけるペレットの気孔率 $[-]$

\section{交献}

1 ) 德田昌則, 吉越英之, 大谷正康：鉄と鋼, 56 (1970), p. 1899

2 ）近江宗一, 碓井建夫：日本金属学会会報, 19
(1980), p. 23

3 ) T. YAGI and Y. ONo: Trans. ISIJ, 8 (1968), p. 377

4) W. E. Ranz and $W . R$. Marshall: Chem. Eng. Progr., 48 (1952), p. 141

5 ) H. W. St. Clair: Trans. Met. Soc. AIME, 233 (1965), p. 1145

6 ）村山武昭，小野陽一，川合保治：鉄と鋼，63 (1977), p. 1099

7 ）渋田勝彦，村山武昭，小野陽一：鉄と鋼，65 (1979), S 614，学振 54 委資料 1497 , 反速 -88 (1979, 7, 25)

8 ) 井口義章, 井上道雄: 鉄と鋼, 65 (1979), p. 1692

9 ) 近江宗一, 内藤誠章, 碓井建夫：鉄と鋼， 66 (1980), S 2 